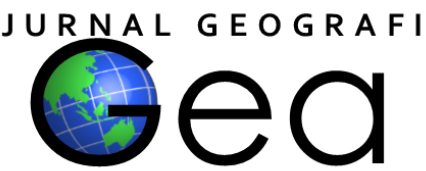

\title{
ANALISIS TINGKAT BAHAYA EROSI PADA WADUK WADASLINTANG DENGAN APLIKASI ARCGIS
}

\author{
Rindang Mekarsasi ${ }^{1}$, Puji Utomo ${ }^{2}$ \\ ${ }^{1,2}$ Program Studi Teknik Sipil, Universitas Teknologi Yogyakarta \\ $\underline{1 \text { rindangmsasi93@gmail.com }}, \underline{2}$ mr.pujiutomo@gmail.com
}

\begin{abstract}
Erosion is one of the events that cannot be avoided in ecosystems, erosion makes various kinds of losses, so that it requires an analysis of the calculation of erosion hazard levels to determine the type of soil conservation that is suitable for mitigating it. The purpose of this study was to find out the Erosion Hazard Level (TBE) that occurred in 2010, 2011 and 2012 in the Wadaslintang Reservoir Wawar Watershed using the ArcGIS application and USLE (Universal Soil Loss Equation). The USLE (Universal Soil Loss Equation) method uses four erosion determinants including rain erosivity $(R)$, soil erodibility $(K)$, slope length and slope $(L S)$ and land use / land cover and soil conservation measures (CP). Erosion Hazard Levels that occur in the Wawar watershed of Wadaslintang Reservoir are dominated by very mild levels, where in 2010-2012 happen in a row for the very mild class on an area of 15912,9226 ha (69,3377\%), 17842,0105 ha $(77,7434 \%), 18071,5515$ ha $(78,7436 \%)$.
\end{abstract}

Keywords: Erosion, Erosion Hazard Level, USLE, Wadaslintang Reservoir.

\begin{abstract}
ABSTRAK
Erosi merupakan salah satu peristiwa yang tidak bisa dihindari dalam ekosistem, terjadinya erosi membuat berbagai macam kerugian, oleh karena itu dibutuhkan suatu analisis perhitungan tingkat bahaya erosi untuk mengetahui jenis konservasi tanah yang sesuai untuk menanggulanginya. Tujuan dari penelitian ini adalah untuk mengetahui Tingkat Bahaya Erosi (TBE) yang terjadi pada tahun 2010, 2011 dan 2012 pada DAS Wawar Waduk Wadaslintang dengan menggunakan aplikasi ArcGIS dan metode USLE (Universal Soil Loss Equation). Metode USLE (Universal Soil Loss Equation) merupakan salah satu metode untuk menganalisis erosi yang menggunakan empat variabel penentu erosi diantaranya erosivitas hujan (R), erodibilitas tanah (K), panjang dan kemiringan lereng (LS) serta penggunaan lahan/penutup lahan dan tindakan konservasi tanah (CP). Tingkat Bahaya Erosi yang terjadi pada DAS Wawar Waduk Wadaslintang didominasi dengan tingkat sangat ringan, dimana pada tahun 2010-2012 secara berturut-turut terjadi pada lahan seluas 15912,9226 ha $(69,3377 \%), 17842,0105$ ha $(77,7434 \%), 18071,5515$ ha $(78,7436 \%)$.
\end{abstract}

Kata kunci: Erosi, Tingkat Bahaya Erosi, USLE, Waduk Wadaslintang. 


\section{PENDAHULUAN}

Erosi dan Sedimentasi merupakan proses terlepasnya butiran tanah dari induknya di suatu tempat dan terangkutnya material tersebut oleh gerakan air atau angin kemudian diikuti dengan pengendapan material yang terdapat di tempat lain (Suripin, 2002). Erosi sangat menentukan berhasil tidaknya suatu pengelolaan lahan. Oleh karena itu, erosi merupakan faktor yang harus dipertimbangkan dalam perencanaan penggunaan lahan dan pengelolaannya.

Proses terjadinya erosi ditentukan oleh faktor-faktor hidrologi terutama intensitas hujan, topografi, karakteristik tanah, vegetasi penutup lahan, dan tata guna lahan. Akumulasi erosi dalam waktu yang lama dapat menambah penumpukan sedimen di dalam waduk, yang berdampak pada penurunan kinerja dan usia waduk.

Perhitungan estimasi erosi dibutuhkan untuk mengetahui besarnya erosi yang terjadi pada suatu lahan yang kemudian dianalisis dan dapat ditentukan klasifikasi tingkat bahaya erosi yang terjadi. Penentuan tingkat bahaya erosi penting untuk dilakukan guna menentukan tindakan konservasi lahan yang sesuai untuk menanggulangi bahaya erosi tersebut.

Penelitian ini menggunakan metode USLE (Universal Soil Loss Equation) dalam mengestimasi erosi dengan mengandalkan tiga data curah hujan dari tiga stasiun hujan yang tersebar pada DAS Wawar Waduk Wadaslintang untuk memperoleh nilai $\mathrm{R}$ (erosivitas hujan). Selain itu, digunakan data sekunder berupa peta jenis tanah untuk mendapatkan nilai K (erodibilitas tanah), peta kemiringan lereng untuk mendapatkan nilai LS (panjang dan kemiringan lereng) dan peta penggunaan lahan untuk mendapatkan nilai CP (penutup lahan dan tindakan konservasi tanah).

\section{METODE PENELITIAN}

Pada penelitian ini memanfaatkan data sekunder yang ada seperti data curah hujan tahun 2010-2012 Balai Pengelolaan Sumber Daya Air (BPSDA) Progo Bogowonto Luk Ulo, peta jenis tanah, kemiringan lereng dan penggunaan lahan yang didapatkan dari Badan Perencanaan dan Pengelolaan Daerah (BAPPEDA) Wonosobo. Setelah mendapatkan data-data sekunder tersebut dilakukan overlay (tumpang susun) pada peta untuk menggabungkan nilai variabel erosi yaitu erosivitas hujan (R), jenis tanah $(\mathrm{K})$, kemiringan lereng (LS) dan penggunaan lahan (CP).

Metode yang digunakan untuk menganalisis erosi pada penelitian ini adalah metode USLE (Universal Soil Loss Equation), pada metode ini dilakukan perkalian antar variabel penentu erosi untuk mendapatkan nilai total erosi yang terjadi pada DAS Wawar Waduk Wadaslintang.

\section{HASIL DAN PEMBAHASAN}

\section{Faktor Erosivitas Hujan (R)}

Faktor erosivitas hujan adalah kemampuan hujan dalam menyebabkan erosi. Pada penelitian ini data curah hujan menggunakan data tiga stasiun hujan yaitu stasiun Kaliwiro, stasiun Limbangan, stasiun Sumberejo dari tahun 2010-2012. Dalam penentuan nilai erosivitas hujan (R) digunakan persamaan menurut (Asdak, 2007).

$$
\mathrm{R}=\frac{\sum_{n}^{\mathrm{i}} E I}{(100 X)}
$$

Rumus diatas merupakan rumus yang digunakan untuk mencari rata-rata nilai erosivitas hujan pada satu tahun, sedangkan pada penelitian ini dibutuhkan nilai erosivitas hujan pada satu tahun, bukan rata-rata. Sehingga dilakukan modifikasi rumus menjadi sebagai berikut:

$$
\mathrm{R}=\frac{\mathrm{EI}}{(100 x 1)}
$$

Dari persamaan tersebut dihasilkan nilai erosivitas hujan (R) tiap stasiun hujan yang dapat dilihat pada Tabel 1. Dan distribusi parsial dari nilai erosivitas hujan $(\mathrm{R})$ dan nilai rata-rata curah hujan tiap luasan stasiun hujan dapat dilihat pada Gambar 1, 2, dan 3. 
Tabel 1. Hasil Perhitungan Erosivitas Hujan 2010-2012

\begin{tabular}{|l|c|c|}
\hline \multicolumn{3}{|c|}{$\mathbf{2 0 1 0}$} \\
\hline \multicolumn{1}{|c|}{ Stasiun Hujan } & Curah Hujan (Ei) & Nilai R \\
\hline Limbangan & 5507 & 55,07 \\
\hline Kaliwiro & 4771 & 47,71 \\
\hline Sumberejo & 5552 & 55,52 \\
\hline \multicolumn{3}{|c|}{$\mathbf{2 0 1 1}$} \\
\hline Limbangan & 5254 & 52,54 \\
\hline Kaliwiro & 4030 & 40,30 \\
\hline Sumberejo & 3138 & 31,38 \\
\hline \multicolumn{2}{|c|}{$\mathbf{2 0 1 2}$} & 42,64 \\
\hline Limbangan & 4264 & 31,42 \\
\hline Kaliwiro & 3142 & 31,9 \\
\hline Sumberejo & 3193 & \multicolumn{2}{|c|}{ Sumber: }
\end{tabular}

Sumber: Olahan peneliti (2019)

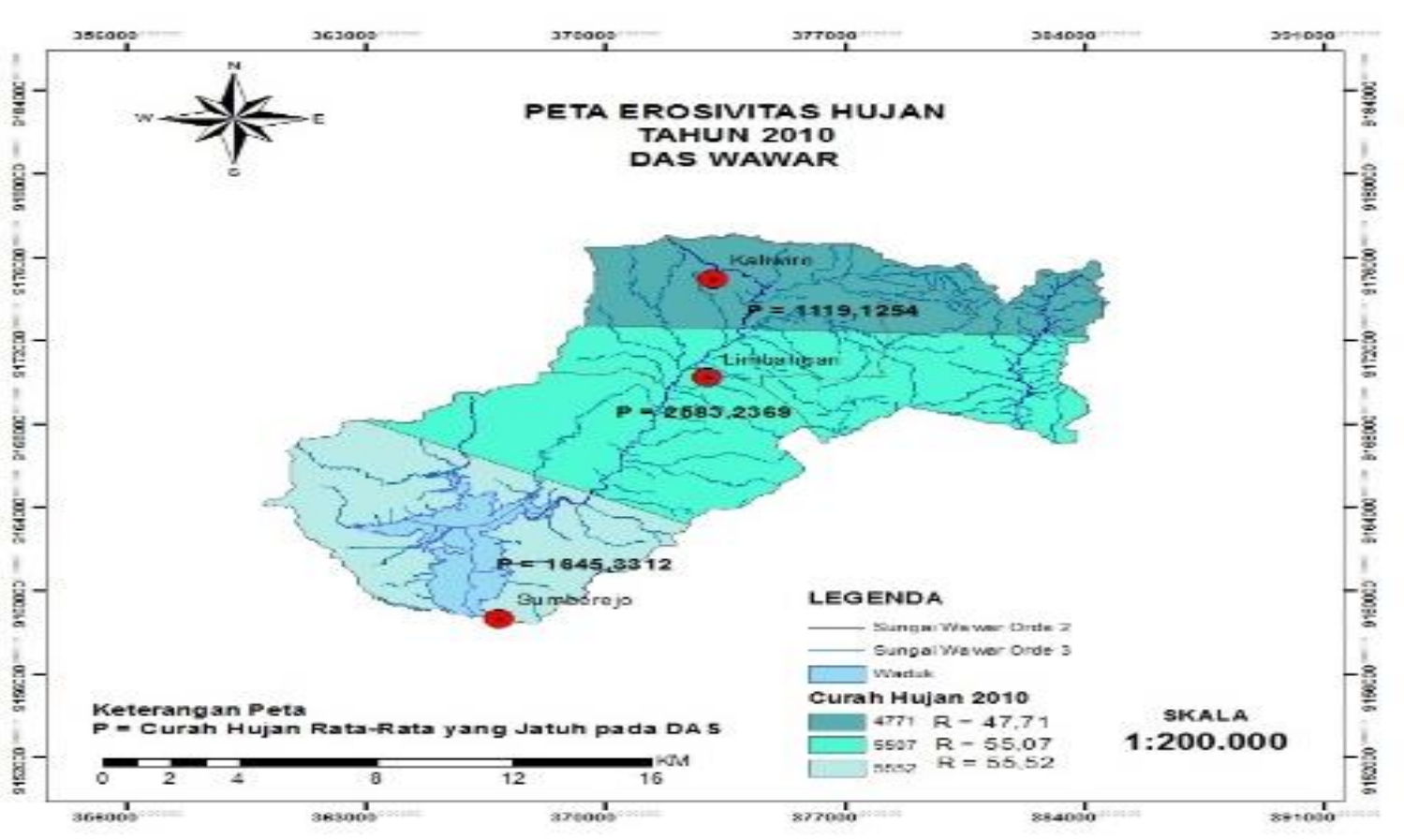

Sumber: Olahan Peneliti, 2019

Gambar 1. Erosivitas Hujan Tahun 2010 


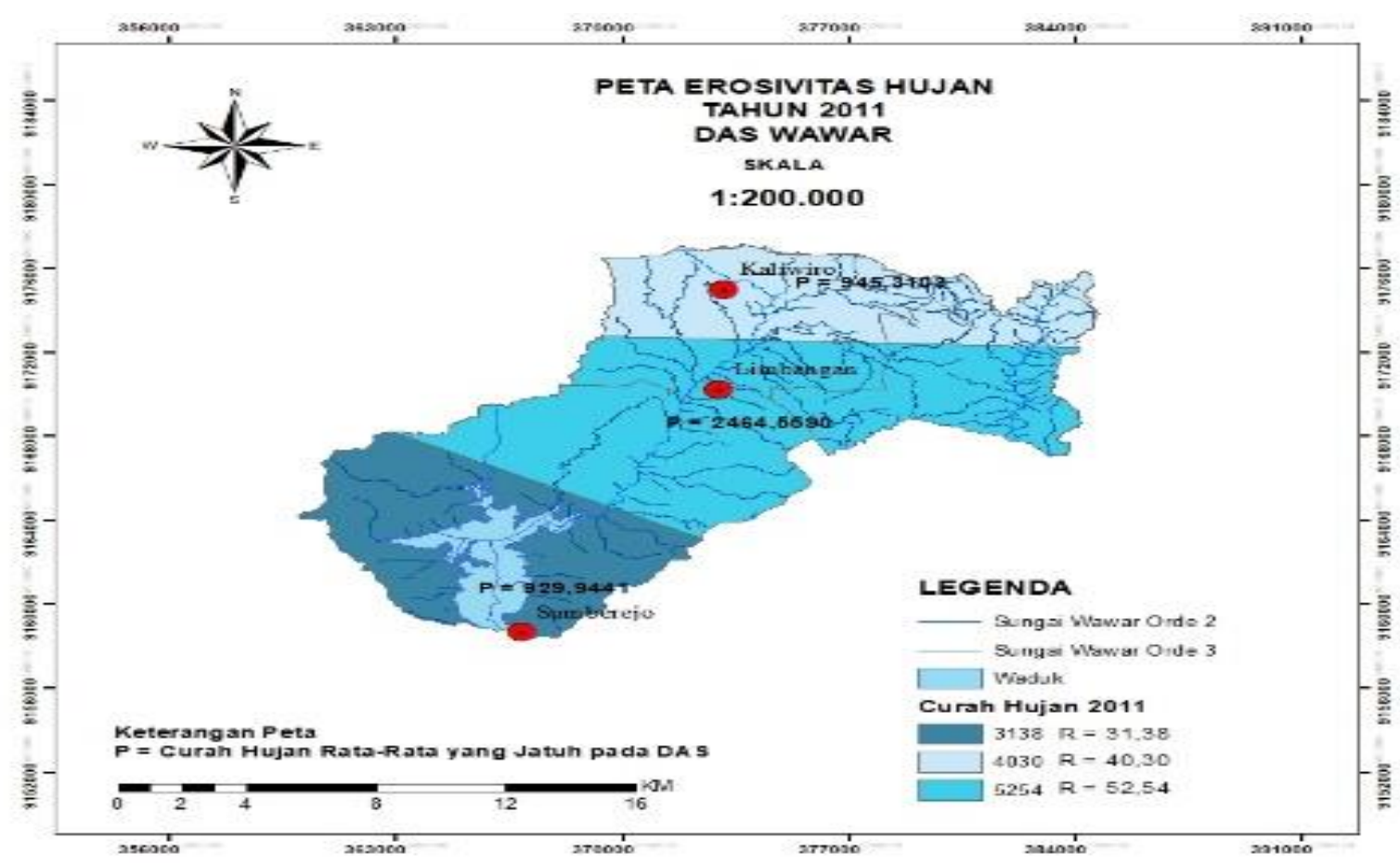

Sumber: Olahan Peneliti, 2019

Gambar 2. Erosivitas Hujan Tahun 2011

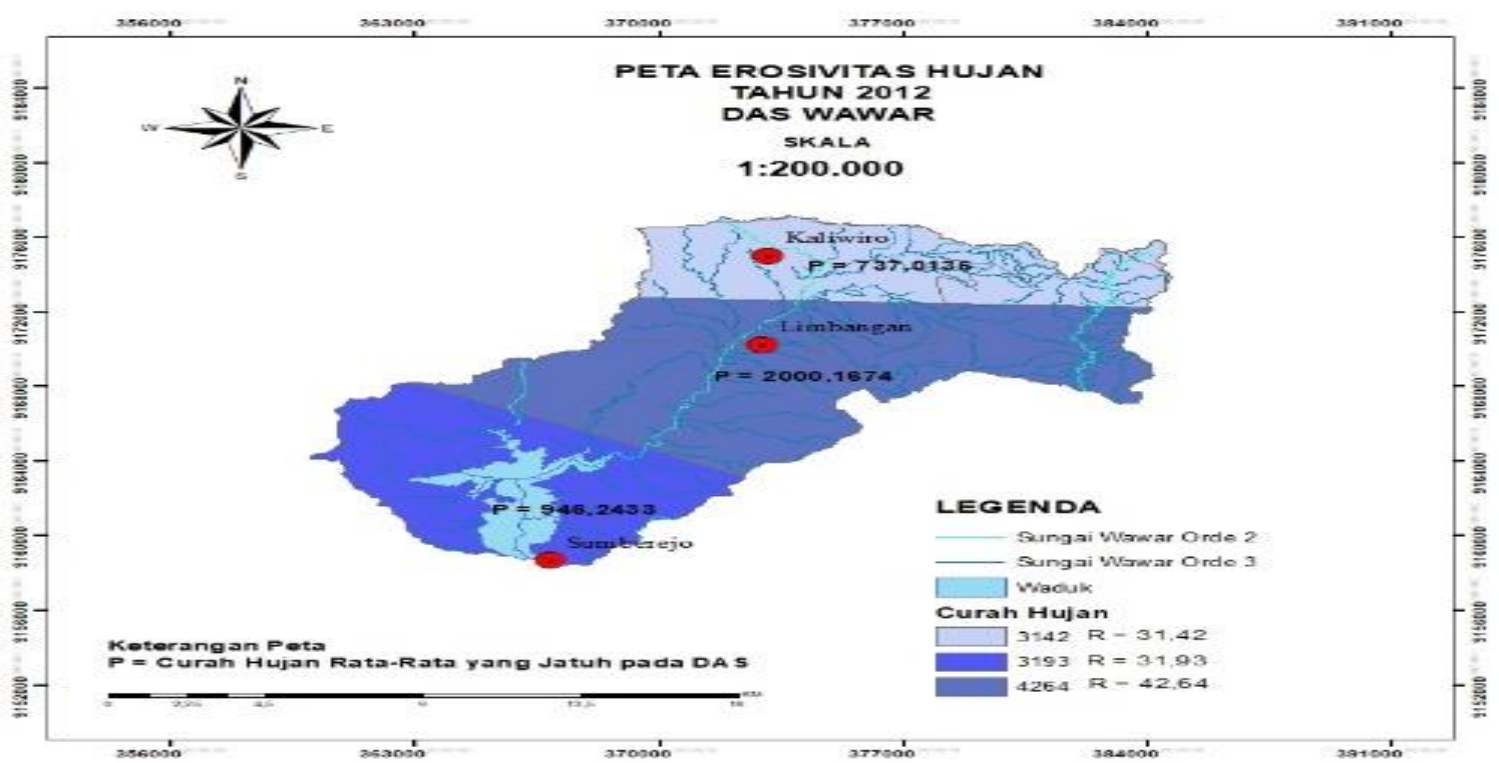

Sumber: Olahan Peneliti, 2019

Gambar 3. Erosivitas Hujan Tahun 2012

2. Faktor Erodibilitas Tanah (K)

Faktor erodibilitas tanah adalah kemampuan tanah dalam menahan proses pengelupasan dan transportasi partikel-partikel tanah karena energi kinetik air hujan. Data-data mengenai jenis tanah diperoleh dari data sekunder berupa peta digital sebaran jenis tanah beserta nilai erodibilitas nilai $(\mathrm{K})$. Jenis tanah yang terdapat pada DAS Wawar Waduk
Wadaslintang didominasi oleh Komplek Latosol Merah Kekuningan Latosol Coklat, Podsolik Merah Kekuningan dengan berpedoman pada Puslitbang Pengairan Bandung dalam Hendrawan (2004) didapatkan nilai $\mathrm{K}$ seperti yang dapat dilihat pada Tabel 2. 
Tabel 2. Nilai K pada Jenis Tanah Waduk Wadaslintang

\begin{tabular}{|l|c|c|c|}
\hline \multicolumn{1}{|c|}{ Jenis Tanah } & Luas (HA) & $\begin{array}{c}\text { \% Luas dari } \\
\text { DAS }\end{array}$ & Nilai K \\
\hline $\begin{array}{l}\text { Komplek Podsolik Merah Ke- } \\
\text { kuningan dan Podsolik Kuning }\end{array}$ & 441,114765 & 1,922078871 & 0,175 \\
\hline Latosol Litosol & 2171,086799 & 9,460123296 & 0,175 \\
\hline $\begin{array}{l}\text { Komplek Latosol Merah Kekuning- } \\
\text { an Latosol Coklat, Podsolik Merah } \\
\text { Kekuningan }\end{array}$ & 20337,6769 & 88,61779783 & 0,116 \\
\hline
\end{tabular}

Sumber: Puslitbang Pengairan Bandung dalam Hendrawan (2004)

Distribusi parsial dari jenis tanah dapat dilihat pada Gambar 4. Yaitu Peta yang ada pada DAS Wawar Waduk Jenis Tanah Das Wawar.

Wadaslintang

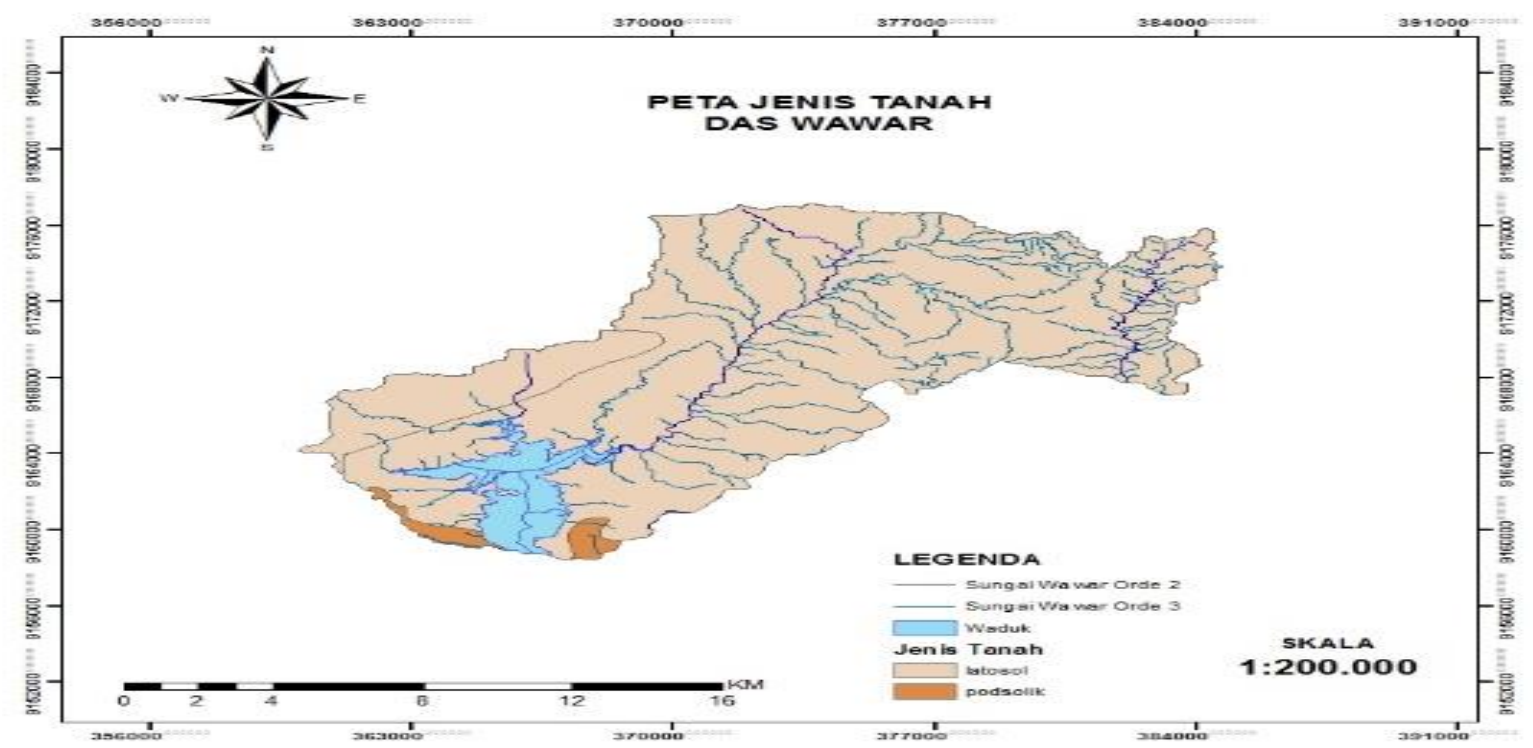

Gambar 4. Jenis Tanah

3. Faktor Kemiringan Lereng (LS)

Faktor indeks topografi $\mathrm{L}$ dan $\mathrm{S}$, masing-masing mewakili pengaruh panjang dan kemiringan lereng terhadap besarnya erosi. Panjang lereng mengacu pada aliran air permukaan, yaitu lokasi berlangsungnya erosi dan kemungkinan terjadinya deposisi sedimen. Dalam menentukan kelas kelerengan digunakan peta digital persebaran kemiringan lereng. Secara umum wilayah DAS Wawar Waduk Wadaslintang memliki kemiringan lereng yang paling dominan ialah $8-15 \%$ dimana dalam kelas kemiringan lereng tersebut masuk kedalam klasifikasi agak curam. Distribusi kemiringan lereng pada DAS Wawar Waduk Wadaslintang dapat dilihat pada Tabel 3. 
Tabel 3. Nilai LS pada DAS Wawar Waduk Wadaslintang

\begin{tabular}{|c|c|c|c|}
\hline Kemiringan Lereng & Luas (ha) & \% Luas dari DAS & Nilai LS \\
\hline $0-8 \%$ & 8429,60208 & 36,73048675 & 0,4 \\
\hline $8-15 \%$ & 10458,7442 & 45,57211126 & 1,4 \\
\hline $15-25 \%$ & 3333,13599 & 14,52354526 & 3,1 \\
\hline $25-40 \%$ & 726,2450 & 3,164483108 & 6,8 \\
\hline$>40 \%$ & 2,1512 & 0,009373624 & 9,5 \\
\hline
\end{tabular}

Distribusi parsial dari kemiringan lereng pada DAS Wawar Waduk Wadaslintang dapat dilihat pada Gambar 5.

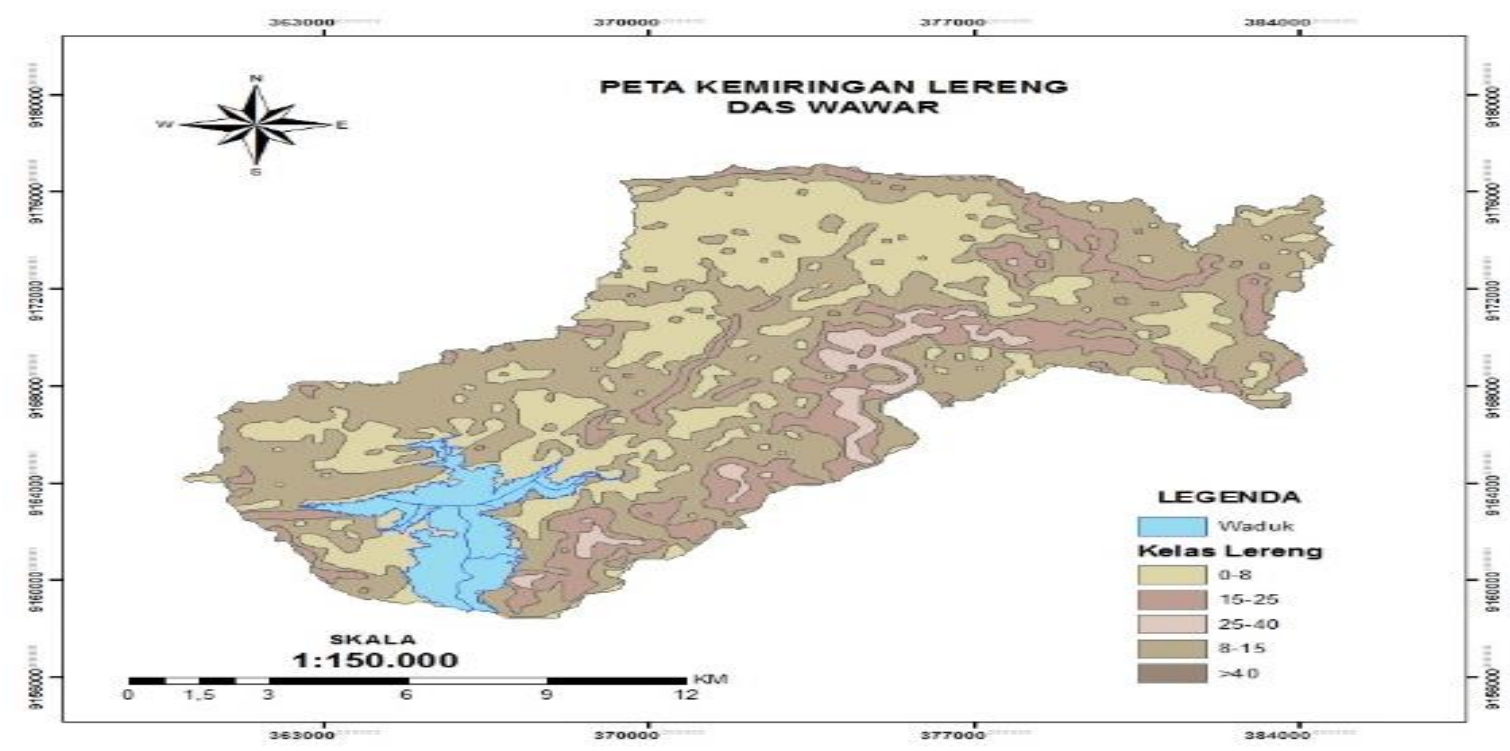

Sumber: Bappeda Wonosobo (2019)

Gambar 5. Persebaran kemiringan lereng DAS Wawar Waduk Wadaslintang

4. Faktor Penggunaan Lahan dan Tindakan Konservasi Tanah (CP)

Faktor penggunaan lahan/penutup lahan dan konservasi tanah dapat diketahui dari peta digital Tata Guna Lahan, kemudian dari peta tersebut dapat diketahui nilai $\mathrm{CP}$ yang ada dengan berpedoman pada tabel nilai CP oleh Arsyad (1995) dan Hammer dalam
Hendrawan (2004) pada penelitian ini penggunaan lahan/penutup lahan didominasi dengan kebun campuran dengan luas 12680,02514 ha atau sekitar $55,251 \%$ dari luas DAS. Tabel nilai CP untuk penggunaan lahan yang ada pada DAS Wawar Waduk Wadaslintang dapat dilihat pada Tabel 4. 
Tabel 4. Nilai CP untuk Penggunaan Lahan DAS Wawar Waduk Wadaslintang

\begin{tabular}{|l|c|c|c|}
\hline \multicolumn{1}{|c|}{$\begin{array}{c}\text { Jenis Penggunaan } \\
\text { Lahan }\end{array}$} & Luas (ha) & \% Luas dari DAS & Nilai CP \\
\hline Bangunan industri & 3,8691 & 0,016858949 & 1 \\
\hline $\begin{array}{l}\text { Bangunan Pemukiman } \\
\text { Desa }\end{array}$ & 1137,1136 & 4,954769697 & 1 \\
\hline Hutan Produksi Terbatas & 3532,6561 & 15,35370264 & 0,2 \\
\hline $\begin{array}{l}\text { Hutan Produksi } \\
\text { tetap }\end{array}$ & 2189,2965 & 9,5394689 & 0,2 \\
\hline Kebun Campuran & 12680,02514 & 55,25094677 & 0,07 \\
\hline $\begin{array}{l}\text { Sawah dengan padi } \\
\text { diselingi palawija }\end{array}$ & 2018,0248 & 8,793183083 & 0,561 \\
\hline Sungai & 60,8418 & 0,26510723 & 0,001 \\
\hline Waduk multifungsi & 1337,0514 & 5,825962735 & 0,001 \\
\hline
\end{tabular}

Sumber: Arsyad, 1995 dan Hammer dalam Hendrawan (2004)

Distribusi parsial dari penggunaan lahan yang terdapat pada DAS Wawar Waduk Wadaslintang dapat dilihat pada Gambar 6.

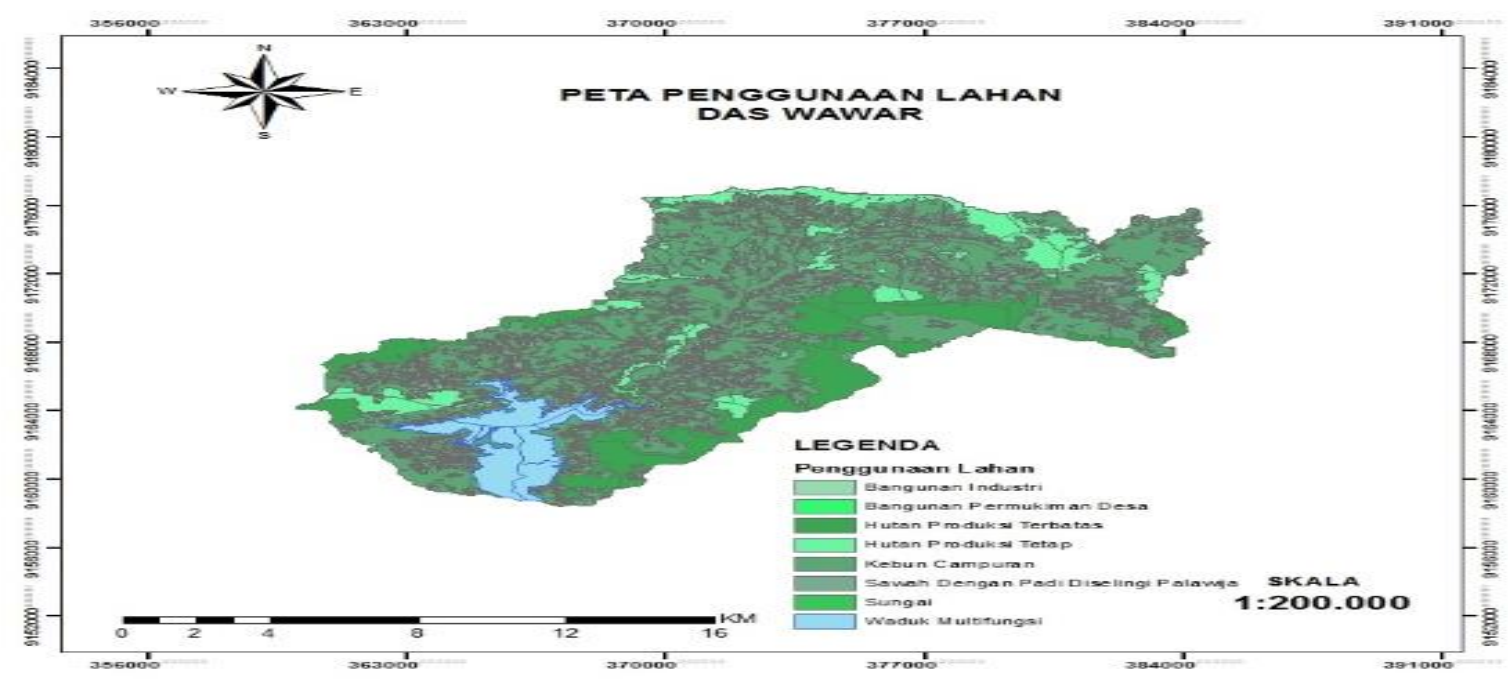

Sumber: Bappeda Wonosobo (2019)

Gambar 6. Peta Penggunaan Lahan

5. Perhitungan Nilai Erosi dengan Metode USLE

Berdasarkan variabel USLE yaitu $\mathrm{R}, \mathrm{K}, \mathrm{LS}, \mathrm{CP}$ masing-masing diatas selanjutnya di overlay dan dilakukan perhitungan dengan cara mengalikan keseluruhan variabel pada masing-masing tahun, sehingga diperoleh data besaran erosi tiap unit satuan lahan. Hasil penjumlahan besaran erosi tiap unit satuan 
unit lahan merupakan nilai total besaran erosi yang terjadi pada suatu DAS pada tahun tertentu. Nilai total erosi yang terjadi pada DAS Wawar Waduk Wadaslintang dengan luas 22949,8785 ha dapat dilihat pada Tabel 6. Persamaan USLE untuk memperkirakan erosi adalah sebagai berikut:

$$
\mathrm{A}=\mathrm{R} \text {. K . LS. CP }
$$

Dari persamaan tersebut, didapatkan hasil nilai total erosi tiap satuan lahan sebagai berikut.

Tabel 5. Nilai Erosi pada Tahun 2010-2012 DAS Wawar Waduk Wadaslintang

\begin{tabular}{|c|c|}
\hline \multicolumn{2}{|c|}{ Total Erosi } \\
\hline Tahun 2010 & 4377,0769 ton/th \\
\hline Tahun 2011 & 3659,2559 ton/th \\
\hline Tahun 2012 & 3072,5716 ton/th \\
\hline
\end{tabular}

Sumber: Olahan Peneliti (2019)

6. Klasifikasi Tingkat Bahaya Erosi

Setelah nilai erosi diperoleh, selanjutnya hal yang dilakukan adalah mengklasifikasi tingkat bahaya erosi. Pada penelitian ini standar penentuan tingkat bahaya erosi berpedoman pada tabel tingkat bahaya erosi menurut Suripin (2002). Klasifikasi tingkat bahaya erosi pada tahun 2010-2012 DAS Wawar Waduk Wadaslintang dapat dilihat pada Tabel 6.

Tabel 6. Klasifikasi Tingkat Bahaya Erosi Tahun 2010-2012 DAS Wawar Waduk Wadaslintang

\begin{tabular}{|c|c|c|}
\hline \multicolumn{3}{|c|}{2010} \\
\hline TBE & Luas (ha) & Persentase (\%) \\
\hline Ringan & 7004,661247 & 30,5216 \\
\hline Sangat Ringan & 15912,9226 & 69,3377 \\
\hline Sedang & 32,2947 & 0,1407 \\
\hline \multicolumn{3}{|c|}{ Total Erosi } \\
\hline TBE & 2011 \\
\hline Ringan & 5081,068035 & 22,13984721 \\
\hline Sangat Ringan & 17842,0105 & 77,74337672 \\
\hline Sedang & 26,7999667 & 0,116776072 \\
\hline \multicolumn{2}{|c|}{ Total Erosi } & 3659,2559 ton/th \\
\hline \multicolumn{2}{|c|}{2012} \\
\hline Ringan & 4878,150542 & 21,25567045 \\
\hline Sangat Ringan & 18071,5515 & 78,74356067 \\
\hline Sedang & 0,176458223 & 0,000768885 \\
\hline \multicolumn{2}{|c|}{ Total Erosi } & 3072,5716 ton/th \\
\hline
\end{tabular}

Distribusi spasial prediksi erosi DAS Waduk Wadaslintang dapat dilihat pada peta distribusi erosi DAS Waduk
Wadaslintang 2010-2012 yang disajikan pada Gambar 7, 8 dan 9. 


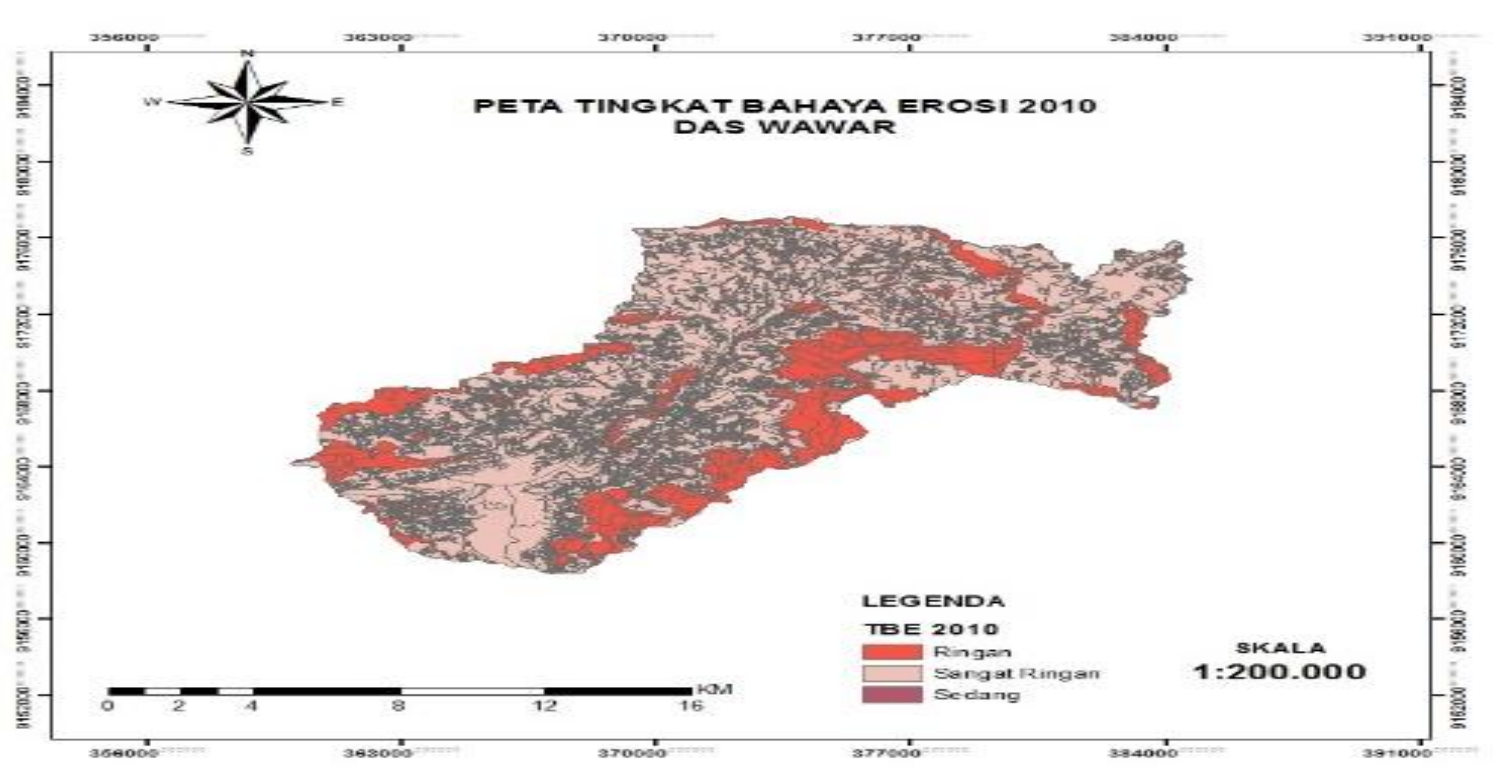

Gambar 7. Peta TBE 2010

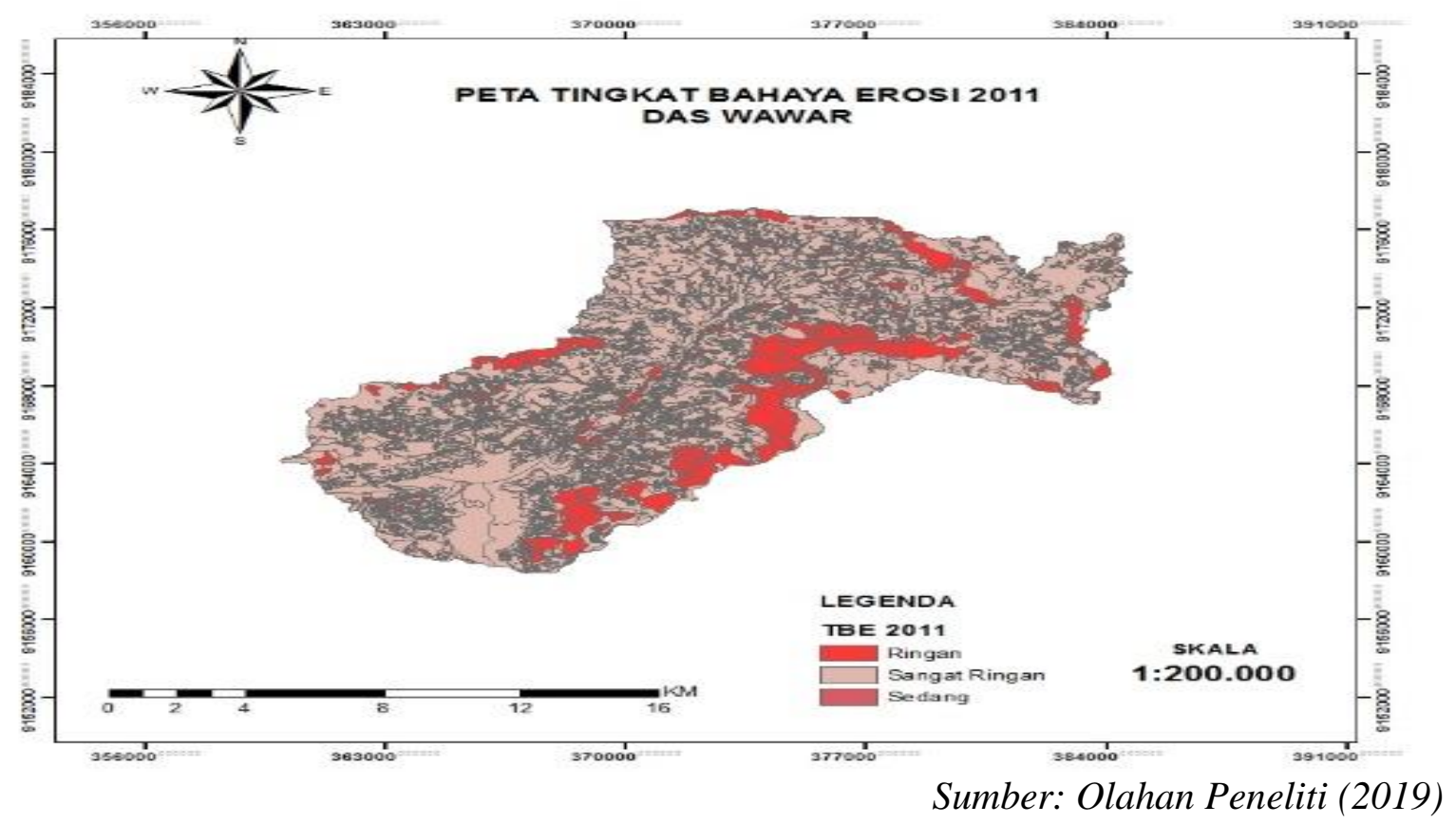

Gambar 9. Peta TBE 2011 


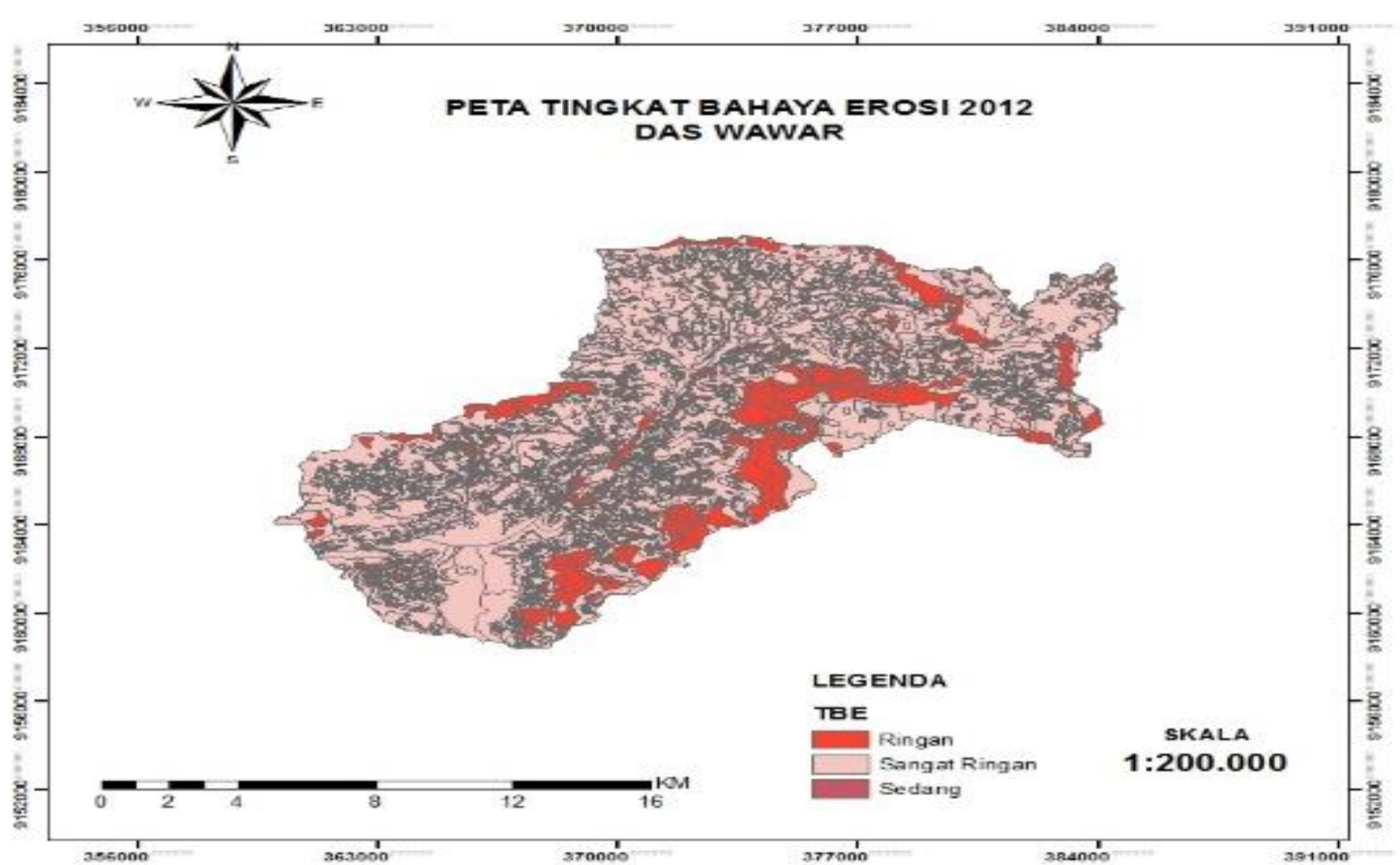

Sumber: Olahan Peneliti (2019)

Gambar 10. Peta TBE 2012

7. Laju Erosi

Dari hasil perhitungan estimasi nilai erosi dengan metode USLE dapat diperhitungkan nilai laju erosi rata-rata pertahun dengan menggunakan persamaan sebagai berikut:

\section{Laju erosi $=\frac{\text { Iumlah EnsiTotal }}{\text { LuasDAS }}$}

Dari hasil persamaan tersebut diperoleh nilai rata-rata laju erosi seperti yang tertera pada Tabel 7.

Tabel 7. Laju Erosi

\begin{tabular}{|c|c|c|}
\hline \multicolumn{2}{|c|}{ Rata-Rata Laju Erosi } & Klasifikasi \\
\hline Tahun 2010 & 0,1907 ton/ha/th & Sangat Ringan \\
\hline Tahun 2011 & 0,1594 ton/ha/th & Sangat Ringan \\
\hline Tahun 2012 & 0,1339 ton/ha/th & Sangat Ringan \\
\hline
\end{tabular}

Sumber: Olahan Peneliti (2019)

\section{Hasil Sedimen (Sediment Yield)}

Sedimen merupakan hasil dari erosi, hasil sedimen sendiri merupakan jumlah total sedimen yang mencapai sungai atau outlet DAS per tahunnya, jumlahnya selalu lebih kecil daripada total erosi yang terjadi di DAS tersebut. Analisis sedimen pada waduk perlu dilakukan karena berpengaruh langsung pada pengurangan kapasitas atau daya tampung waduk. Analisis hasil sedimen pada waduk dapat dilakukan dengan persamaan:

$$
\mathrm{Y}=\mathrm{E}(\mathrm{SDR}) \mathrm{Ws}
$$

Dalam perhitungan hasil sedimen diperlukan nilai nisbah pelepasan sedimen. Nilai nisbah pelepasan sedimen merupakan rasio antara jumlah sedimen yang terangkut ke dalam sungai terhadap jumlah erosi yang terjadi di dalam DAS disebut dengan Nisbah Pelepasan Sedimen atau Sediment Delivery Ratio (SDR). Dalam 
mendapatkan nilai SDR digunakan tabel pengaruh luas DAS terhadap SDR sebagai

berikut.

Tabel 8. Pengaruh Luas DAS Terhadap SDR

\begin{tabular}{|c|c|c|}
\hline No. & Luas DAS (ha) & Rasio Pelepasan Sedimen (\%) \\
\hline 1 & 10 & 53 \\
\hline 2 & 50 & 39 \\
\hline 3 & 100 & 35 \\
\hline 4 & 500 & 27 \\
\hline 5 & 1000 & 24 \\
\hline 6 & 5000 & 15 \\
\hline 7 & 10000 & 13 \\
\hline 8 & 20000 & 11 \\
\hline 9 & 50000 & 8.5 \\
\hline 10 & 2600000 & 4.9 \\
\hline
\end{tabular}

Sumber: Robinson (1979) dalam Arsyad (2012)

Hasil perhitungan nilai hasil sedimen pada

DAS Wawar Waduk Wadaslintang dapat

dilihat pada Tabel 9.

Tabel 9. Hasil Sedimen DAS Wawar Waduk Wadaslintang

\begin{tabular}{|c|c|}
\hline Tahun & Hasil Sedimen (ton/tahun) \\
\hline 2010 & 470,653 \\
\hline 2011 & 393,404 \\
\hline 2012 & 330,469 \\
\hline
\end{tabular}

Sumber: Olahan Peneliti (2019)

\section{SIMPULAN}

a. Nilai total estimasi erosi yang terjadi pada DAS Wawar Waduk Wadaslintang di tahun 2010-2012 secara berturut-turut adalah 4377,0769 ton/tahun, 3659,2559 ton/tahun dan 3072,5716 ton/tahun. Nilai total erosi terbesar jatuh pada tahun 2010 dan pada tahun selanjutnya cenderung mengalami penurunan, hal tersebut dapat terjadi karena curah hujan yang cukup tinggi terjadi pada tahun 2010 dibanding tahun-tahun setelahnya. b. Klasifikasi tingkat bahaya erosi yang terjadi pada DAS Wawar Waduk Wadaslintang di tahun 2010-2012 didominasi pada kelas sangat ringan dimana pada tahun 2010 kelas sangat ringan terjadi pada lahan seluas 15912,92259 ha $(69,3377 \%)$ pada tahun 2011 pada lahan seluas 17842,0105 ha $(77,7434 \%)$ dan pada tahun 2012 pada lahan seluas $18071,5515 \quad$ (78,7436\%). Terjadi peningkatan pada tiap tahun di kelas sangat ringan, hal tersebut dapat terjadi karena adanya faktor erosivitas 
hujan yang semakin menurun pada tiap tahunnya sehinga nilai erosi semakin turun dan klasifikasi sangat ringan menjadi meningkat.

\section{REKOMENDASI}

Perlu dilakukan pengkajian lebih lanjut mengenai analisis tingkat bahaya erosi pada DAS Wawar Waduk Wadaslintang terutama pada saat menghitung nilai erosivitas hujan, ada baiknya menggunakan data yang lebih lengkap supaya perhitungan lebih akurat. Perlu dilakukan pengkajian lebih lanjut mengenai tata guna lahan pada DAS Wawar dengan melakukan penyesuaian data tata guna lahan dengan software citra satelit landsat agar lebih akurat.

Sebagai waduk multifungsi, Waduk Wadaslintang memiliki potensi besar terhadap kelangsungan kehidupan baik dari segi pembangkit listrik tenaga air maupun sarana irigasi bagi wilayah disekitarnya. Penanggulangan erosi lahan pada DAS Wawar Waduk Wadaslintang sebaiknya dilakukan untuk keberlangsungan umur waduk.

\section{DAFTAR PUSTAKA}

Alie, M.E.R. (2015). Kajian Erosi Lahan pada DAS Dawas Kabupaten Musi Banyuasin Sumatera Selatan. Palembang: Universitas Sriwijaya.

Asriadi, A. et al (2018). Ringkasan Teori Erosi dan Sedimentasi. Sorong: Universitas Muhammadiyah Sorong.

Chay, A. (1995). Hidrologi dan Pengelolaan Daerah Aliran Sungai. Yogyakarta: Gadjah Mada University Press.

Fauzi, R.M.Z. (2016). Kajian Erosi dan Hasil Sedimen untuk Konservasi Lahan DAS Kreo Hulu. Semarang: Universitas Dipenogoro.

Kironoto, B.A. (2003). Transpor Sedimen. Yogyakarta: PPS-Teknik Sipil.
Nursholeh, A. (2012). Penentuan Laju Erosi Daerah Tangkapan Hujan (DTH) Waduk Wadaslintang Tahun 2004 dan 2008 Menggunakan Teknologi Sistem Informasi Geografis (SIG), Semarang: Universitas Negeri Semarang.

Prasetya, I. R. (2017). Analisis Sedimen dengan Menggunakan Software HECHMS Versi 4.2. Yogyakarta: Universitas Gadjah Mada.

Purnama, N. R. (2008). Pendugaan Erosi dengan Metode USLE (Universal Soil Loss Equation) di Situ Bojongsari, Depok. Bogor: Institut Pertanian Bogor.

Rizalihadi, M. et al. (2015). Model Hubungan Erosi dan Sedimentasi di Waduk Keuling, Aceh Besar. Aceh: Universitas Syiah Kuala.

Triatmodjo, B. (2008). Hidrologi Terapan. Yogyakarta: Gadjah Mada University Press.

Wischmeier, W.H., \& Smith, D. D. (1978). Predicting Rainfall Erosion Losses: a Guide to Conservation Palnning. USA: U.S Department of Agriculture. 